\title{
Moisture Sorption Isotherm and Thermal Characteristics of Freeze-Dried Tuna
}

\author{
Mohammad Shafiur Rahman ${ }^{\mathrm{a}}$, Mohammed Khalfan Al-Khusaibi ${ }^{\mathrm{a}^{*}}$, Kutaila Abbas \\ AL-FArsi $^{\mathrm{a}}$, Ismail Mohamed Al-Bulushi ${ }^{\mathrm{a}}$, Aisha Abushelaibi ${ }^{\mathrm{b}}$, And Nasser \\ AL-HABSI ${ }^{\mathrm{a}}$ \\ ${ }^{\text {a }}$ Department of Food Science and Nutrition, College of Agricultural and Marine Sciences, Sultan Qaboos \\ University, P. O. Box 34-123, Al-Khod 123, Oman \\ ${ }^{\mathrm{b}}$ Food Science Department, College of Food and Agriculture, UAE University \\ ${ }^{*}$ Corresponding author \\ mohamedk@squ.edu.om \\ TEL: +96824143682 \\ FAX: +96824413418
}

Received: 14 May 2018; Published online: 18 April 2019

\begin{abstract}
Water activity is considered an important factor in assessing the stability of food. Understanding the relationship between water activity and equilibrium moisture content (moisture sorption isotherm) benefits food processing in terms of modeling of drying and estimation of shelf life. In addition, glass transition helps to quantify molecular mobility which helps in determining the stability of food. The aim of this study was to determine the moisture sorption isotherm and thermal characteristics of freezedried tuna. These characteristics will help in determining the monolayer moisture and glassy state of the product, at which food is considered most stable. Moisture sorption isotherm at $20^{\circ} \mathrm{C}$ and thermal characteristics (over a wide temperature range i.e. from -90 to $250{ }^{\circ} \mathrm{C}$ ) of freeze-dried tuna flesh were measured. Isotherm data were modeled by BET (Brunauer-Emmett-Teller) and GAB (GuggenheimAnderson-De Boer) models. The GAB and BET monolayer water values were determined as 0.052 and $0.089 \mathrm{~g} \mathrm{~g}^{-1}$ dry-solids (dry-basis), respectively. In the case of samples at moisture contents above $0.10 \mathrm{~g} \mathrm{~g}^{-1}$ (wet basis), DSC (Differential Scanning Calorimetry) thermograms showed two-step state changes (i.e. two glass transitions), one exothermic peak (i.e. molecular ordering) and another endothermic peak (i.e. solids-melting). However, the sample at moisture content of $0.046 \mathrm{~g} \mathrm{~g}^{-1}$ showed three-step state changes (i.e. three glass transitions). The multiple glass transition could be explained by the natural heterogeneity of tuna flesh and inhomogeneity due to molecular incompatibility of the different compositions. The moisture content did not affect the first glass transition temperature nor the exothermic peak $(\mathrm{p}>0.05)$, whereas the third glass transition temperature decreased (i.e. plasticized) with increasing moisture content $(\mathrm{p}<0.05)$. The solids-melting peak temperature decreased, and enthalpy increased with decreasing moisture content $(\mathrm{p}<0.05)$.
\end{abstract}

Keywords: Dried fish; Sorption isotherm; Tuna; Thermal transition; Solids-melting

\section{Introduction}

Water interacts with different ingredients present in foods. This interaction is important in determining the physical, chemical and microbial stability of the foods (Bhandari \& Howes, 1999; Rahman, 2006; Sablani, Kasapis, Rahman, AlJabri, \& Al-Habsi, 2004). Water activity is considered an important property to determine the 
stability of foods compared to the total amount of water (Labuza, Mcnally, Gallagher, Hawkes, \& Hurtado, 1972; Roos, 1993; Scott, 1953). Therefore, the water activity concept is commonly used to determine the stability of foods in relation to microbial growth, lipid oxidation, non-enzymatic and enzymatic activities, and the texture of foods (Labrousse, Roos, \& Karel, 1992; Shi, Zhao, Chen, Li, \& Xue, 2009; Shimada, Roos, \& Karel, 1991). In addition, it is used as a tool in food processing operations, such as modeling of drying processes, estimating shelf-life, and choosing suitable packaging material for a food product (Orlien, Risbo, Andersen, \& Skibsted, 2003). Water activity is related to the moisture content in the sorption isotherm (i.e. the relationship of water activity and equilibrium moisture content) (Delgado \& Sun, 2002).

Recently, it has been observed that the water activity concept is not sufficient to determine stability of food, thus glass transition has been proposed to quantify molecular mobility (Delgado \& Sun, 2002; Karel, Buera, \& Roos, 1993; Karmas, Buera, \& Karel, 1992; Sablani et al., 2004; Slade \& Levine, 1988, 1991). Foods are considered most stable when they are stored at or below their glass transition because of the low molecular mobility of the reactants in a highly viscous medium. This reduced mobility could significantly retard microbial and chemical reactions (Meste, Champion, Roudaut, Blond, \& Simatos, 2002; Rahman, 2006). As the storage temperature increases above the glass transition temperature, foods become less stable with increased molecular mobility (Goula, Karapantsios, Achilias, \& Adamopoulos, 2008; Sablani et al., 2007; Syamaladevi, Sablani, Tang, Powers, \& Swanson, 2010; Tonon et al., 2009). The water activity and glass transition concepts could be combined to determine the stability of foods (Rahman, 2009; Rahman \& Al-Saidi, 2017; Shi et al., 2009).

Fresh tuna fish has a short shelf life unless it is stored at very low temperatures or dried (Orlien et al., 2003). It is important to measure the thermal characteristics and sorption isotherm in order to determine efficient processing and storage stability of dried tuna (Roos \& Karel, 1991). Glass transition of different types of fish and other muscle tissues like chicken and beef are reported in the literature (Brake \& Fennema,
1999; Sablani et al., 2007; Tolstorebrov, Eikevik, \& Bantle, 2014). Harnkarnsujarit, Kawai, and Suzuki (2015) measured the glass transition and water sorption isotherm of water extract from freeze-dried tuna. Most probably, they attempted to simplify the complex intact structure into a sample of only soluble components. Moreover, their temperature range in Differential Scanning Calorimetry (DSC) was within 80 to $80^{\circ} \mathrm{C}$ without measuring solids-melting or solids-decomposition. However, there are negligible data available on the thermal characteristics of dried fish (i.e. whole sample) over a wide range of temperature (i.e. including solidsmelting or solids-decomposition) (Suresh, AlHabsi, Guizani, \& Rahman, 2017). The structural collapse during drying processes influenced water uptake during rehydration, which could be related to a glassy state of dried fish (Marques, Prado, \& Freire, 2009). The hygroscopicity was also affected by different drying methods and affected the sorption isotherm (Caparino et al., 2012). The aim of this study was to determine the moisture sorption isotherm and thermal characteristics (i.e. -90 to $250^{\circ} \mathrm{C}$ ) of freeze-dried tuna. These characteristics could be used to determine monolayer moisture and glassy state, which is considered the best stability during processing and storage.

\section{Materials and Methods}

\subsection{Sample Preparation}

Fresh yellowfin tuna (Thunnus albacares) was purchased from a local fish market and brought (iced) within $30 \mathrm{~min}$ to the laboratory. Tuna was harvested overnight by the fisherman and ice-stored in the boat. Tuna was landed in the morning and displayed at the beach fish market (i.e. around $10 \mathrm{hr}$ after harvest). The fillets were prepared and diced at room temperature (i.e. $20{ }^{\circ} \mathrm{C}$ ) into $3 \mathrm{~cm}$ cubes; and placed into several $50 \mathrm{ml}$ plastic containers. The diced cubes were then frozen at $-40{ }^{\circ} \mathrm{C}$ for $24 \mathrm{~h}$ and freeze-dried at room temperature $\left(20{ }^{\circ} \mathrm{C}\right.$ ) (i.e. sample enter at $-40{ }^{\circ} \mathrm{C}$ and dried at $20{ }^{\circ} \mathrm{C}$ ) under vacuum of $200 \mathrm{~Pa}$ for $96 \mathrm{~h}$ using an Edwards K4 Freeze Dryer (Corawky, Crawley, England). 
Freeze-dried tuna was then ground into powder using a KMF grinder (KIKA Werke, Wilmington, USA) running at $6000 \mathrm{rpm}$, and stored at $-20{ }^{\circ} \mathrm{C}$ until used for the DSC experiments.

\subsection{Moisture Sorption Isotherm}

The isopiestic method was used to develop the moisture sorption isotherm (Rahman \& Hamed Al-Belushi, 2006). In this method, $1 \mathrm{~g}$ of freeze-dried tuna powder was placed in an open bottle and stored in an air-sealed glass jar containing a saturated salt solution (for example, lithium chloride) in a $50 \mathrm{ml}$ beaker to maintain a specific relative humidity environment in the jar. Thymol in a $5 \mathrm{ml}$ beaker was also placed inside the jar to prevent the growth of molds during storage. The salts used were lithium chloride, potassium acetate, magnesium chloride, potassium carbonate, magnesium nitrate, sodium nitrate, sodium chloride, potassium chloride and potassium nitrate (water activity: $0.1-0.9)$ and the water activity values were taken from Rahman (1995). The air-sealed glass jars were then stored at $20^{\circ} \mathrm{C}$ for 3 to 4 weeks until equilibrium was reached. This temperature was close to commonly used room temperature storage. Equilibrium conditions were achieved when there was no loss or gain of mass $( \pm 0.01 \mathrm{~g})$ for two consecutive days. Weight was monitored using an analytical balance (OHAUS, model AS200, Florham Park, USA). The moisture content was determined by an oven method according to AOAC (2005), by drying $1 \mathrm{~g}$ of the sample in a conventional hot-air oven at $105^{\circ} \mathrm{C}$ for at least $20 \mathrm{~h}$ until a constant weight was achieved. The moisture content in the sorption isotherm data was expressed in dry basis as commonly presented in the literature. Each water activity data collection was replicated 3 times.

The moisture sorption isotherms were modeled using Brunauer-Emme-Teller (BET) (Brunauer, Emmet, \& Teller, 1938) and Guggenheim-Andersen-de Boer (GAB) equations (Bizot, 1983). BET and GAB equations are as follows:

$$
M_{w}=\frac{M_{b m} B a_{w}}{\left(1-a_{w}\right)\left[1+(B-1) a_{w}\right]}
$$

$$
M_{w}=\frac{M_{g m} C K a_{w}}{\left(1-K a_{w}\right)\left(1-K a_{w}+C K a_{w}\right)}
$$

where, $M_{w}, M_{b m}$, and Mgm are the moisture content at any water activity, BET-monolayer water content and GAB monolayer water content, respectively (all in $\mathrm{g} \mathrm{g}^{-1}$ dry-solids), $a_{w}$ is the water activity, $B$ is the parameter of BET model, and $C$ and $K$ are the parameters of the GAB model. The BET equation has been widely used and been found to give a good fit when water activities are less than 0.45 . The GAB model has been found to be successful up to water activities as high as 0.9 (Basu, Shivhare, \& Mujumdar, 2006; Al-Muhtaseb, McMinn, \& Magee, 2002).

\subsection{Differential Scanning Calorimetry}

Differential Scanning Calorimetry (DSC) was used to determine state and phase transitions in freeze-dried tuna (Rahman, Al-Saidi, Guizani, \& Abdullah, 2010). The samples containing different moisture (i.e. $0.10,0.15$, and $0.20 \mathrm{~g}$ $\mathrm{g}^{-1}$ sample, wet basis) were prepared from the freeze-dried sample (initial moisture of $0.046 \mathrm{~g}$ $100 \mathrm{~g}^{-1}$ sample, wet basis) by spraying the desired amount of distilled water and mixing thoroughly with a spatula. The samples were then stored at $4{ }^{\circ} \mathrm{C}$ for $24 \mathrm{~h}$ for equilibration. After equilibration, samples were stored at $-20{ }^{\circ} \mathrm{C}$ for 24 hours until they were used for DSC measurements. The samples were analyzed thermally in a DSC (Q200, TA Instrument, New Castle, DE, USA) and the thermal characteristics were determined. The instrument was calibrated using indium with melting temperature of $156.5^{\circ} \mathrm{C}$ and enthalpy of $28.5 \mathrm{~J} \mathrm{~g}^{-1}$.

Samples of 3 to $5 \mathrm{mg}$ of freeze-dried tuna were placed in Tzero aluminum hermetic pans and sealed. The pans containing the samples were cooled from 25 to $-90{ }^{\circ} \mathrm{C}$ at a rate of $5^{\circ} \mathrm{C} \mathrm{min}^{-1}$ and then heated to $250{ }^{\circ} \mathrm{C}$ at $10^{\circ} \mathrm{C}$ min $^{-1}$ under nitrogen (carrier gas) purged at $50 \mathrm{~mL} \mathrm{~min}{ }^{-1}$. An empty pan was used as a reference. Thermograms were obtained in triplicates for the samples with different moisture contents and these were analyzed for exothermic (i.e. ordering in molecules) and endothermic (i.e. solids-melting) peaks and shifts in the thermogram (i.e. glass 
$90 \mid$ Rahman et al.

transition). The moisture content of samples used for the DSC analysis is expressed in wet basis as commonly presented in the literature.

\subsection{Statistical Analysis}

Each value is presented as mean \pm standard deviation. A non-linear regression analysis was used to estimate the parameters of the isotherm models (i.e. Guggenheim-Anderson-de Boer, GAB and Brunauer-Emmett-Teller, BET). The significant effect of moisture on the thermal characteristics was determined using ANOVA (Microsoft Excel, 2010).

\section{Results and Discussion}

\subsection{Moisture Sorption Isotherm}

Figure 1 shows the moisture sorption isotherm of tuna flesh at $20^{\circ} \mathrm{C}$. The data were fitted with BET and GAB models and the parameters are presented in Table 1 with their prediction accuracy. The BET and GAB monolayer water values were 0.089 and $0.052 \mathrm{~g} \mathrm{~g}^{-1}$ dry-solids, respectively, and samples at BET monolayer water could be considered most stable since deteriorative chemical reactions are minimal (Rahman \& Hamed Al-Belushi, 2006; Sablani et al., 2007). However, the GAB model is useful for predicting water activity over the complete range of moisture up to 0.90. In the case of king fish flesh (fat content: $0.039 \mathrm{~g} \mathrm{~g}^{-1}$ sample), BET and GAB monolayer water content were found to be 0.036 and $0.052 \mathrm{~g} \mathrm{~g}^{-1}$ dry-solids, respectively (Sablani et al., 2007). The same authors analysed fatfree king fish and they found values of 0.048 and 0.086 for the BET and GAB models, respectively. This indicated that fat content marginally increased the monolayer values. Delgado and Sun (2002) reported values of 0.073 and 0.068 $\mathrm{g} \mathrm{g}^{-1}$ dry-solids, respectively for chicken meat (fat content: $0.004 \mathrm{~g} \mathrm{~g}^{-1}$ sample). The main variations of the monolayer values depended on the types of proteins. It was reported that fat content had very small or negligible effects as a plasticizer when added to protein (Kalichevsky, Jaroszkiewicz, \& Blanshard, 1992; Shaw, Monahan, O'Riordan, \& O'Sullivan, 2002). Fat free protein, such as gelatine and collagen showed high BET and GAB monolayers, 0.12 and $0.10 \mathrm{~g}$ $\mathrm{g}^{-1}$ dry-solid, respectively (Timmermann, Chirife, \& Iglesias, 2001).

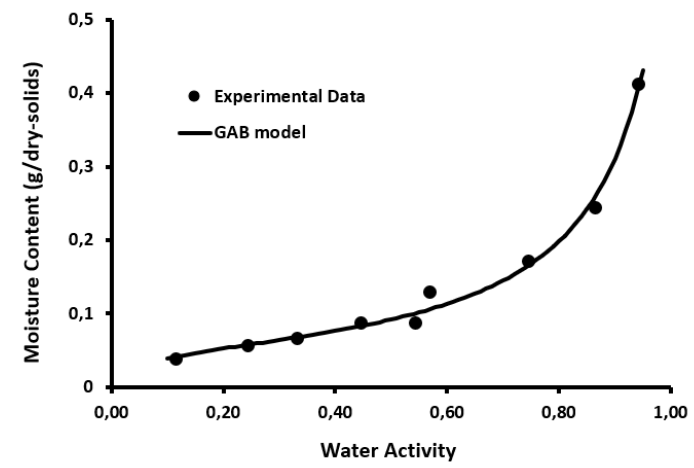

Figure 1: Experimental moisture sorption isotherm of freeze-dried tuna and predicted GAB model

\subsection{Thermal Characteristics}

A typical DSC thermogram for freeze dried tuna is shown in Figure 2 (moisture content: $0.046 \mathrm{~g}$ $\mathrm{g}^{-1}$ sample, wet basis). Three letters A, B and $\mathrm{C}$ represent three transitions however, they could not be visualized clearly due to the high exothermic and endothermic enthalpy (i.e. high heat flow). Therefore, these regions were expanded with the appropriate scales and are shown in Figure 3. Figure 2 also shows an exothermic peak (i.e. molecular ordering) and an endothermic peak (i.e. solids-melting). The sample at moisture $0.046 \mathrm{~g} \mathrm{~g}^{-1}$ showed three glass transitions, while other samples showed only two glass transitions. This additional shift (i.e. $T_{g i}: 97.6 \pm 5.7$ ${ }^{\circ} \mathrm{C}, T_{g p}: 103.2 \pm 8.2{ }^{\circ} \mathrm{C}, T_{g e}: 104.7 \pm 8.2{ }^{\circ} \mathrm{C}, \Delta C_{p}$ : $400 \pm 120 \mathrm{~J} \mathrm{~kg}^{-1} \mathrm{~K}^{-1}$ ) was observed between the first and the third glass transition. Table 2 shows two glass transitions (first and third) as a function of moisture content. At moisture content

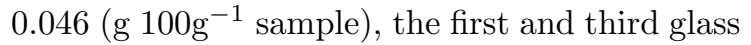
transitions were observed at 28.3 and $148.5^{\circ} \mathrm{C}$, respectively (Table 2). Similarly, Tolstorebrov et al. (2014) observed variation in the glass transition onset temperature from 36.6 to $40.3{ }^{\circ} \mathrm{C}$ 
in the case of vacuum dried cod, salmon, trout, herring and mackerel at a moisture of $0.055 \mathrm{~g}$ $\mathrm{g}^{-1}$ sample. This transition was close to the values of the first transition observed in the case of tuna. In the case of king fish muscle samples (moisture content: $0.035 \mathrm{~g} \mathrm{~g}^{-1}$ sample), Sablani et al. (2007) observed two glass transitions, one at $-11.0^{\circ} \mathrm{C}$ and the other at $74.7^{\circ} \mathrm{C}$. In the case of air-dried tuna (moisture: $0.046 \mathrm{~g} \mathrm{~g}^{-1}$ sample), (Rahman, Kasapis, Guizani, \& Al-Amri, 2003) observed a glass transition at $67.1^{\circ} \mathrm{C}$, as measured by mechanical thermal analysis. Their value was relatively close to the second glass transition $97.6{ }^{\circ} \mathrm{C}$. In the case of water-soluble extract of freeze-dried tuna, one glass transition was observed, and it was plasticized with the increase of water content (i.e. more hydrophilic components) (Harnkarnsujarit et al., 2015). The whole freeze-dried sample was more rigid and amorphous, and the plasticization process was hindered although water content increased. Earlier, it was identified that multicomponent food systems could show multi-glass transitions (Biliaderis, 1991; Hashimoto, Hagiwara, Suzuki, \& Takai, 2003).

Table 1: BET and GAB model parameters for moisture sorption isotherm of dried tuna

\begin{tabular}{lll}
\hline Model & Parameter & \\
\hline GAB & $\mathrm{M}_{b m}$ & $0.052 \mathrm{~g} \mathrm{~g}^{-1}$ dry solid \\
& $\mathrm{K}$ & 0.926 \\
& $\mathrm{C}$ & 19.36 \\
& $\mathrm{r}^{2}$ & 0.99 \\
& $\mathrm{SE}$ & 0.013 \\
& $\mathrm{p}$-value & $<0.05$ \\
$\mathrm{BET}$ & $\mathrm{M}_{g m}$ & $0.089 \mathrm{~g} \mathrm{~g}^{-1}$ dry solid \\
& $\mathrm{B}$ & 4.038 \\
& $\mathrm{r}^{2}$ & 0.95 \\
& $\mathrm{SE}$ & 0.0056 \\
& $\mathrm{p}$-value & $<0.05$ \\
\hline
\end{tabular}

Moisture content in freeze-dried tuna did not affect the first glass transition temperature $(\mathrm{p}>$ $0.05)$ and specific heat change at that transition $(\mathrm{p}>0.05)$, whereas the third glass transition temperature decreased $(\mathrm{p}<0.05)$ and specific

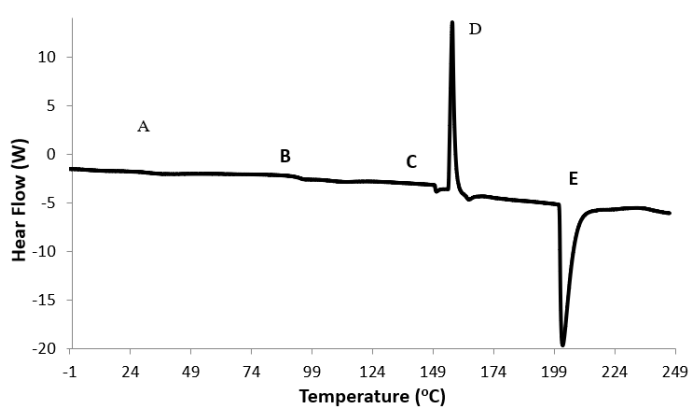

Figure 2: A typical DSC thermogram of freezedried tuna at a moisture content $4.6 \mathrm{~g} 100 \mathrm{~g}-1$ sample, A: first glass transition, B: second glass transition, C: third glass transition, D: exothermic peak (i.e. molecular ordering, E: endothermic peak (i.e. solids-melting)

heat change increased with the increase of moisture content $(\mathrm{p}<0.05)$ (Table 2). Similarly, in the case of king fish, Sablani et al. (2007) did not observe any plasticization (i.e. decrease of glass transition) with water for the first glass transition. In the case of the third glass transition (i.e. in tuna), higher water contents decreased glass transition due to plasticization, and increased specific heat change, which suggested the formation of hydrogen bonding causing the development of disordered structure (i.e. more amorphous domain) (Rahman \& Al-Saidi, 2017). In the case of sugar-based foods containing freezable water, two glass transitions were commonly observed, one at low temperature and another just below ice-melting temperature (Rahman, 2004). In the case of tuna, the low glass transition temperature did not plasticize with increasing water content. However, glass transition temperature before melting decreased with the increase of water content (i.e. plasticized). In the case of rice, Cao, Nishiyama, and Koide (2004) observed three transitions, and the second transition showed a significant decrease with increasing moisture, while first and third transitions remained stable with increasing moisture. They hypothesized that the second transition could be the glass transition as plasticization (i.e. decrease of glass transition) occurred at this transition. The multiple glass transitions could be 

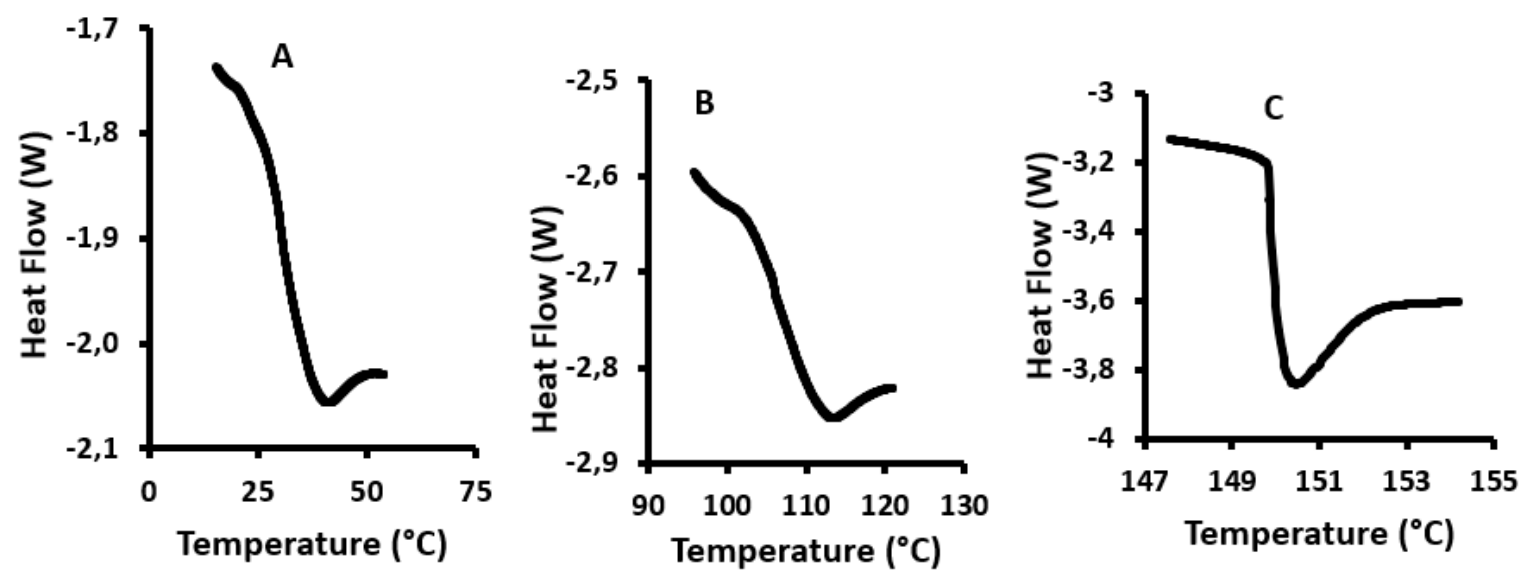

Figure 3: Expansion of the glass transitions as marked in Figure 2. A: first glass transition, B: second glass transition, $\mathrm{C}$ : third glass transition

Table 2: First and third glass transitions of freeze-dried tuna

\begin{tabular}{lllllllll}
\hline \multicolumn{7}{l}{ First Glass Transition } \\
\hline $\mathrm{Xw}$ & $\mathrm{T}_{g i}$ & $\mathrm{~T}_{g p}$ & $\mathrm{~T}_{g e}$ & $\Delta \mathrm{C}_{p}$ & $\mathrm{~T}_{g i}$ & $\mathrm{~T}_{g p}$ & $\mathrm{~T}_{g e}$ & $\Delta \mathrm{C}_{p}$ \\
& $\left({ }^{\circ} \mathrm{C}\right)$ & $\left({ }^{\circ} \mathrm{C}\right)$ & $\left({ }^{\circ} \mathrm{C}\right)$ & $\left(\mathrm{J} \mathrm{kg}-1{ }^{o} \mathrm{C}^{-1}\right)$ & $\left({ }^{o} \mathrm{C}\right)$ & $\left({ }^{o} \mathrm{C}\right)$ & $\left({ }^{o} \mathrm{C}\right)$ & $\left(\mathrm{J} \mathrm{kg}^{-1}{ }^{o} \mathrm{C}^{-1}\right)$ \\
0.046 & $28.3 \pm 0.5$ & $29.9 \pm 0.4$ & $34.1 \pm 1.1$ & $300 \pm 50$ & $148.5 \pm 1.2$ & $148.6 \pm 1.1$ & $148.8 \pm 1.2$ & $510 \pm 170$ \\
0.100 & $30.9 \pm 0.7$ & $32.1 \pm 0.6$ & $35.5 \pm 0.9$ & $184 \pm 3$ & $138.2 \pm 0.1$ & $138.2 \pm 0.1$ & $138.4 \pm 0.1$ & $530 \pm 180$ \\
0.150 & $30.6 \pm 0.8$ & $32.5 \pm 2.0$ & $35.7 \pm 1.3$ & $207 \pm 8$ & $134.1 \pm 2.3$ & $134.1 \pm 2.3$ & $134.2 \pm 2.4$ & $630 \pm 230$ \\
0.200 & $31.9 \pm 2.1$ & $33.8 \pm 2.7$ & $35.7 \pm 1.6$ & $192 \pm 12$ & $131.7 \pm 2.5$ & $131.8 \pm 2.6$ & $132.0 \pm 2.6$ & $760 \pm 240$ \\
& $\mathrm{p}>0.05$ & & & $\mathrm{p}>0.05$ & $\mathrm{p}<0.05$ & & & $\mathrm{p}<0.05$ \\
\hline
\end{tabular}

Note:

Each data point is presented as mean \pm Standard deviation and p-value was set at 0.05 for determining significance

$\mathrm{Xw}$ : water content (g water/g sample), $\mathrm{T}_{g i}$ : initial glass transition temperature, $\mathrm{T}_{g p}$ : peak glass transition temperature, $\mathrm{T}_{g e}$ : end of glass transition temperature; $\Delta \mathrm{Cp}$ : change in specific heat capacity 
Stability of freeze-dried tuna $\mid 93$

Table 3: Characteristics of exothermic and endothermic (i.e. solids-melting) peaks of freeze-dried tuna

\begin{tabular}{lllllllll}
\hline $\mathrm{Xw}$ & $\begin{array}{l}\mathrm{T}_{e a} \\
\left({ }^{\circ} \mathrm{C}\right)\end{array}$ & $\begin{array}{l}\mathrm{T}_{e p} \\
\left({ }^{o} \mathrm{C}\right)\end{array}$ & $\begin{array}{l}\mathrm{T}_{e e} \\
\left({ }^{o} \mathrm{C}\right)\end{array}$ & $\begin{array}{l}\Delta \mathrm{H}_{e} \\
\left(\mathrm{~kJ} \mathrm{~kg}^{-1}\right)\end{array}$ & $\begin{array}{l}\mathrm{T}_{m i} \\
\left({ }^{o} \mathrm{C}\right)\end{array}$ & $\begin{array}{l}\mathrm{T}_{m p} \\
\left({ }^{o} \mathrm{C}\right)\end{array}$ & $\begin{array}{l}\mathrm{T}_{m e} \\
\left({ }^{o} \mathrm{C}\right)\end{array}$ & $\begin{array}{l}\Delta \mathrm{H}_{m} \\
\left(\mathrm{~kJ} \mathrm{~kg}^{-1}\right)\end{array}$ \\
\hline 0.046 & $155.5 \pm 0.4$ & $157.0 \pm 0.5$ & $161.4 \pm 0.4$ & $36.1 \pm 1.1$ & $202.2 \pm 1.4$ & $203.2 \pm 1.6$ & $217.9 \pm 1.2$ & $85 \pm 7$ \\
0.100 & $155.5 \pm 0.2$ & $157.0 \pm 0.2$ & $161.7 \pm 0.2$ & $37.1 \pm 2.3$ & $188.4 \pm 3.6$ & $188.4 \pm 3.5$ & $202.7 \pm 2.5$ & $151 \pm 9$ \\
0.150 & $155.4 \pm 0.2$ & $156.9 \pm 0.2$ & $160.9 \pm 1.4$ & $31.3 \pm 3.4$ & $175.8 \pm 3.8$ & $181.6 \pm 5.0$ & $192.1 \pm 3.6$ & $166 \pm 6$ \\
0.200 & $155.5 \pm 0.4$ & $156.9 \pm 0.5$ & $161.1 \pm 0.8$ & $34.6 \pm 2.6$ & $176.8 \pm 0.8$ & $176.7 \pm 1.8$ & $189.6 \pm 3.0$ & $299 \pm 5$ \\
& $\mathrm{p}>0.05$
\end{tabular}

explained by the natural heterogeneity of biological materials, such as meat and fish muscle and the inhomogeneity due to molecular incompatibility in complex foods (Orlien et al., 2003).

Table 3 shows the exothermic and endothermic peaks as a function of moisture content. It was observed that the moisture content did not affect the exothermic peak and enthalpy ( $p>$ 0.05). The average values of the peak temperature and enthalpy were $155.5 \pm 0.1{ }^{\circ} \mathrm{C}$ and $34.8 \pm 2.5 \mathrm{~kJ} \mathrm{~kg}^{-1}$, respectively. Similarly, in the case of freeze-dried broccoli, Suresh et al. (2017) observed an exothermic peak before the solidsmelting endothermic. The exothermic peak indicated that there was an order in the molecules at the higher temperature before melting. The endothermic peak can be considered as solidsmelting (i.e. softening of the solid phase as proteins denature with the release of heat). The peak temperature decreased and enthalpy increased with the decrease of moisture $(\mathrm{p}<0.05)$. Protein denaturation can be noticed as an endothermic peak in the DSC curve in the temperature range of $40-80{ }^{\circ} \mathrm{C}$ in case of fresh food samples (i.e. high moisture content) (Hashimoto et al., 2003). The peak temperature increased (e.g., $120{ }^{\circ} \mathrm{C}$ ) as sample moisture content decreased. It was suggested that protein denaturation significantly affected the glass transition of protein-rich food (Hashimoto, Suzuki, Hagiwara, \& Takai, 2004; Sochava \& Smirnova, 1993; Wright, Leach, \& Wilding, 1977). The increase of enthalpy during solids melting could be explained by the formation of more hydrogen bonds at higher water content. A similar trend was observed in the case of freeze-dried broccoli (Suresh et al., 2017).

Considering the water activity concept, stability of freeze dried samples could be achieved if stored at $0.089 \mathrm{~g} \mathrm{~g}^{-1}$ dry-solids at room temperature (i.e. $20^{\circ} \mathrm{C}$ ). The two or three state changes (i.e. glass transitions) indicated that different types of physico-chemical changes could occur in the tuna sample. The lower one is important if freezedried fish is to be stored at room temperature and higher glass transition is relevant in roasting and frying processes. Further studies need to be conducted for determining the types of chemical reactions that could occur at the different stages of glass transitions.

\section{Conclusions}

Moisture sorption isotherm of freeze-dried tuna was measured and modeled by BET and GAB equations. The BET and GAB monolayer water content were 0.052 and $0.089 \mathrm{~g} \mathrm{~g}^{-1}$ dry-solids, respectively. In this work, isotherm was measured at $20{ }^{\circ} \mathrm{C}$ (i.e. close to usual sale display, around $18-20^{\circ} \mathrm{C}$ ). However, further work at extreme conditions, such as $10{ }^{\circ}$ or $30{ }^{\circ} \mathrm{C}$, could provide enriched information on the effects of temperature on isotherm. For a sample with moisture content of $0.046 \mathrm{~g} \mathrm{~g}^{-1}$, three glass transitions were observed at different temperatures, first one onset at $28.3^{\circ} \mathrm{C}$, second one at $97.6^{\circ} \mathrm{C}$, and third at $148.5^{\circ} \mathrm{C}$. However, samples at higher moisture 
content showed only two glass transitions; one at low and the other at higher temperature. The lower glass transition was un-affected by moisture content, whereas higher temperature glass transitions decreased with increasing moisture content. Similarly, solids-melting (i.e. protein denaturation) decreased with increasing moisture content. In addition, specific heat change at the glass transition and enthalpy at solidsmelting increased with the increase of water content. The sample used in this study was powder to simplify sample handling and measurement. The thermal transitions may not be changed for powder or intact solid samples, however kinetics of moisture sorption would be faster in the case of powder samples, although final equilibrium conditions would be unaffected. This point needs to be considered when freeze-dried samples are stored.

\section{Acknowledgements}

This project was funded by SQU-UAEU Project (CL/SQU-UAEU/15/03) and authors would like to thank Sultan Qaboos University and United Arab Emirates University for their support during this collaborative work.

\section{References}

AOAC. (2005). Solids (Total) and Moisture in Flour, Method 925.10. Official Methods of Analysis, 18th Edition, AOAC International, Gaithersburg.

Basu, S., Shivhare, \& Mujumdar, A. (2006). Models for sorption isotherms for foods: A review. Drying Technology, 24 (8), 917-930. doi:10.1080/07373930600775979

Bhandari, B., \& Howes, T. (1999). Implication of glass transition for the drying and stability of foods. Journal of Food Engineering, 40(1-2), 71-79. doi:10.1016/S02608774(99)00039-4

Biliaderis, C. G. (1991). Non-equilibrium phase transitions of aqueous starch systems. In Water relationships in foods (pp. 251-273). Springer.
Bizot, H. (1983). Using the 'gab' model to construct sorption isotherms. Physical Properties of Foods, 43-54.

Brake, N. C., \& Fennema, O. R. (1999). Glass transition values of muscle tissue. Journal of Food Science, 64 (1), 10-15. doi:10.1111/ j.1365-2621.1999.tb09851.x

Brunauer, S., Emmet, P. H., \& Teller, E. (1938). Adsorption of gases in multimolecular layers. Journal of the American Chemical Society, 60(2), 309-319. doi:10 . $1021 /$ ja01269a023

Cao, W., Nishiyama, Y., \& Koide, S. (2004). Physicochemical, mechanical and thermal properties of brown rice grain with various moisture contents. International Journal of Food Science and Technology, 39, 899-906. doi:10.1111/j.1365-2621.2004.00849.x

Caparino, O., Tang, J., Nindo, C., Sablani, S., Powers, J., \& Fellman, J. (2012). Effect of drying methods on the physical properties and microstructures of mango (philippine 'carabao' var.) powder. Journal of Food Engineering, 111(1), 135-148. doi:10.1016/ j.jfoodeng.2012.01.010

Delgado, A., \& Sun, D.-W. (2002). Desorption isotherms and glass transition temperature for chicken meat. Journal of Food Engineering, 55(1), 1-8. doi:10.1016 / S02608774(01)00222-9

Goula, A., Karapantsios, T., Achilias, D., \& Adamopoulos, K. (2008). Water sorption isotherms and glass transition temperature of spray dried tomato pulp. Journal of Food Engineering, 85(1), 73-83. doi:10.1016/j. jfoodeng.2007.07.015

Harnkarnsujarit, N., Kawai, K., \& Suzuki, T. (2015). Effects of freezing temperature and water activity on microstructure, color, and protein conformation of freeze-dried bluefin tuna (thunnus orientalis). Food and Bioprocess Technology, 8(4), 916-925. doi:10. 1007/s11947-014-1460-1

Hashimoto, T., Hagiwara, T., Suzuki, T., \& Takai, R. (2003). Study on the glass transition of katsuobushi (boiled and dried bonito fish stick) by differential scanning calorimetry and dynamic mechanical analysis. Fisheries Science, 69(6), 1290-1297. doi:10.1111/j.0919-9268.2003.00757.x 
Hashimoto, T., Suzuki, T., Hagiwara, T., \& Takai, R. (2004). Study on the transition for several processed fish muscles and its protein fractions using differential scanning calorimetry. Fisheries Science, 70(6), 1144-1152. doi:10.1111/j.1444-2906.2004. 00916.x

Kalichevsky, M., Jaroszkiewicz, E., \& Blanshard, J. (1992). Glass transition of gluten. 2: The effect of lipids and emulsifiers. International Journal of Biological Macromolecules, 14(5), 267-273. doi:10.1016/ S0141-8130(05)80039-X

Karel, K., Buera, M. P., \& Roos, Y. (1993). The science and technology of the glassy state in foods. In J. M. V. Blanshard \& P. J. Lillford (Eds.), (Chap. Effects of glass transitions on processing and storage, pp. 13-34). Nottingham University Press.

Karmas, R., Buera, P., \& Karel, M. (1992). Effect of glass transition on rates of nonenzymatic browning in food. Journal of Agricultural and Food Chemistry, 40, 873. doi:10.1021/ jf00017a035

Labrousse, S., Roos, Y., \& Karel, M. (1992). Collapse and crystallization in amorphous matrices with encapsulated compounds. Journal of Food Science, 12, 757-769.

Labuza, T., Mcnally, L., Gallagher, D., Hawkes, J., \& Hurtado, F. (1972). Stability of intermediate moisture foods. 1. lipid oxidation. Journal of Food Science, 37, 154-159. doi:10.1111/j.1365-2621.1972.tb03408.x

Marques, L. G., Prado, M. M., \& Freire, J. T. (2009). Rehydration characteristics of freeze-dried tropical fruits. LWT - Food Science and Technology, 42(7), 1232-1237. doi:10.1016/j.lwt.2009.02.012

Meste, M. L., Champion, D., Roudaut, G., Blond, G., \& Simatos, D. (2002). Glass transition and food technology: A critical appraisal. Journal of Food Science, 67(7), 2444-2458. doi:10.1111/j.1365-2621.2002. tb08758.x

Al-Muhtaseb, A., McMinn, W. A. M., \& Magee, T. R. A. (2002). Moisture sorption isotherm characteristics of food products: A review. Food and Bioproducts Processing, 80(2), 118-128. doi:10 . 1205/ 09603080252938753
Orlien, V., Risbo, J., Andersen, M., \& Skibsted, L. (2003). The question of high- or low-temperature glass transition in frozen fish. construction of the supplemented state diagram for tuna muscle by differential scanning calorimetry. Journal of Agricultural and Food Chemistry, 51(1), 211-217. doi:10.1021/jf020355x

Rahman, M. (1995). Water activity and sorption properties of food, chapter 1. Food Properties Handbook, 1-65.

Rahman, M. (2004). State diagram of date flesh using differential scanning calorimetry (dsc). International Journal of Food Properties, 7(3), 407-428. doi:10.1081/JFP 200032930

Rahman, M. (2006). State diagram of foods: Its potential use in food processing and product stability. Trends in Food Science and Technology, 17(3), 129-141. doi:10.1016/j. tifs.2005.09.009

Rahman, M. (2009). Food stability beyond water activity and glass transtion: Macro-micro region concept in the state diagram. International Journal of Food Properties, 12(4), 726-740. doi:10.1080/10942910802628107

Rahman, M., \& Hamed Al-Belushi, R. (2006). Dynamic isopiestic method (dim): Measuring moisture sorption isotherm of freezedried garlic powder and other potential uses of dim. International Journal of Food Properties, 9(3), 421-437. doi:10 . 1080/ 10942910600596134

Rahman, M., \& Al-Saidi, G. (2017). Exploring validity of the macro-micro region concept in the state diagram: Browning of raw and freeze-dried banana slices as a function of moisture content and storage temperature. Journal of Food Engineering, 203, 32-40. doi:10.1016/j.jfoodeng.2017.01.017

Rahman, M., Al-Saidi, G., Guizani, N., \& Abdullah, A. (2010). Development of state diagram of bovine gelatin by measuring thermal characteristics using differential scanning calorimetry (dsc) and cooling curve method. Thermochimica Acta, 509(1-2), 111-119. doi:10.1016/j.tca.2010.06.011

Rahman, S. M., Kasapis, S., Guizani, N., \& AlAmri, O. S. (2003). State diagram of tuna meat: Freezing curve and glass transition. 
$96 \mid$ Rahman et al.

Journal of Food Engineering, 57(4), 321326. doi:10.1016/S0260-8774(02)00346-1

Roos, Y. H. (1993). Water activity and physical state effects on amorphous food stability. Journal of Food processing and Preservation, 16(6), 433-447. doi:10.1111/j.17454549.1993.tb00221.x

Roos, Y., \& Karel, M. (1991). Applying state diagrams to food processing and development. Food technology, 45(12), 66, 68-71, 107.

Sablani, S., Kasapis, S., Rahman, M., AlJabri, A., \& Al-Habsi, N. (2004). Sorption isotherm and the state diagram for evaluating stability criteria of abalone. Food Research International, 37(10), 915-924. doi:10.1016/j.foodres.2004.05.006

Sablani, S., Rahman, M., Al-Busaidi, S., Guizani, N., Al-Habsi, N., Al-Belushi, R., \& Soussi, B. (2007). Thermal transitions of king fish whole muscle, fat and fat-free muscle by differential scanning calorimetry. Thermochimica Acta, 462(1-2), 56-63. doi:10. 1016/j.tca.2007.06.008

Scott, W. J. (1953). Water relations of S. aureus at $30^{\circ} \mathrm{C}$. Australian Journal of Biological Sciences, 6(4), 549-64. doi:10.1071/ BI9530549

Shaw, N. B., Monahan, F. J., O'Riordan, E. D., \& O'Sullivan, M. (2002). Effect of soya oil and glycerol on physical properties of composite wpi films. Journal of Food Engineering, 51(4), 299-304. doi:10.1016/S02608774(01)00071-1

Shi, Q., Zhao, Y., Chen, H.-H., Li, J.-Z., \& Xue, C.-H. (2009). Glass transition and state diagram for freeze-dried horse mackerel muscle. Thermochimica Acta, 493(1-2), 55-60. doi:10.1016/j.tca.2009.04.006

Shimada, Y., Roos, Y., \& Karel, M. (1991). Oxidation of methyl linoleate in amorphous lactose based food model. Journal of Agricultural and Food Chemistry, 39, 637. doi:10.1021/jf00004a001

Slade, L., \& Levine, H. (1988). Non-equilibrium behavior of small carbohydrate-water systems. Pure and Applied Chemistry, 60, 1841-1864. doi:10.1351/pac198860121841

Slade, L., \& Levine, H. (1991). Beyond water activity: Recent advances based on an alternative approach to the assessment of food quality and safety. Critical Reviews in Food Science and Nutrition, 30, 115-360. doi:10. 1080/10408399109527543

Sochava, I. V., \& Smirnova, O. I. (1993). Heat capacity of hydrated and dehydrated globular proteins. denaturation increment of heat capacity. Food Hydrocolloids, 6(6), 513524. doi:10.1016/S0268-005X(09)80075-1

Suresh, S., Al-Habsi, N., Guizani, N., \& Rahman, M. (2017). Thermal characteristics and state diagram of freeze-dried broccoli: Freezing curve, maximal-freezeconcentration condition, glass line and solids-melting. Thermochimica Acta, 655, 129-136. doi:10.1016/j.tca.2017.06.015

Syamaladevi, M. R., Sablani, S., Tang, J., Powers, J., \& Swanson, B. (2010). Water sorption and glass transition temperatures in red raspberry (rubus idaeus). Thermochimica Acta, 503, 90-96. doi:10.1016/j.tca. 2010.03.013

Timmermann, E. O., Chirife, J., \& Iglesias, H. A. (2001). Water sorption isotherms of foods and foodstuffs: Bet or gab parameters? Journal of Food Engineering, 48(1), 19-31. doi:10.1016/S0260-8774(00)00139-4

Tolstorebrov, I., Eikevik, T., \& Bantle, M. (2014). A DSC study of phase transition in muscle and oil of the main commercial fish species from the North-Atlantic. Food Research International, 55, 303-310. doi:10. 1016/j.foodres.2013.11.026

Tonon, R., Baroni, A., Brabet, C., Gibert, O., Pallet, D., \& Hubinger, M. (2009). Water sorption and glass transition temperature of spray dried açai (euterpe oleracea mart.) juice. Journal of Food Engineering, 94(34), 215-221. doi:10.1016/j.jfoodeng. 2009. 03.009

Wright, D. J., Leach, I. B., \& Wilding, P. (1977). Differential scanning calorimetric studies of muscle and its constituent proteins. Journal of the Science of Food and Agriculture, 28(6), 557-564. doi:10.1002/ jsfa . 2740280614 